\title{
POLISH REVOLT (1863 - 1864) IN PUBLICATIONS OF I.S. AKSAKOV
}

\section{REVOLUCIÓN POLACA (1863-1864) EN PUBLICACIONES DE I.S. AKSAKOV}

\author{
Victor K. Khegay ${ }^{1}$, Vladimir V. Blokhin ${ }^{2}$, Mariya V. Yashina ${ }^{3}$
}

Enviado: 27 de junio de 2019

Aceptado para publicar: 30 de julio de 2019

Publicado: 8 de agosto de 2019

\begin{abstract}
In the article, the analysis of judgments of a revolt is provided in the Polish Kingdom and Western edge of one of the main ideologists of Slavophilism of I.S. Aksakov. The key moments of its paradigm on this problem are analyzed, the attempt to discover the reasons for the transformation of views of the Slavophile of the Polish events is made. It is revealed that the aggressive methods of fight practiced by rebels caused resistant hostility in Aksakov and other Slavophiles.
\end{abstract}

Keywords: I.S. Aksakov, Polish revolt, "Polish question", Slavophiles, Western edge, Europe.

En el artículo, el análisis de los juicios de una revuelta se proporciona en el Reino de Polonia y el borde occidental de uno de los principales ideólogos del eslavofilismo de I.S. Aksakov Se analizan los momentos clave de su paradigma sobre este problema, se hace el intento de descubrir las razones de la transformación de las opiniones del eslavófilo de los acontecimientos polacos. Se revela que los métodos agresivos de lucha practicados por los rebeldes causaron hostilidad resistente en Aksakov y otros eslavófilos.

Palabras clave: I.S. Aksakov, revuelta polaca, "pregunta polaca", eslavófilos, borde occidental, Europa. 


\section{Introduction}

Justification of a subject. Events of 1863 - 1864 in Poland and the western areas of the empire split the Russian society into adherents of insurgent ideas and adherents of maintaining the integrity of Russia. Liberals and conservatives, revolutionary democrats and anarchists, Slavophiles and Westerners - figures of these directions defended the civic stand both in the press and on public statements. Did not add harmony to the relations between different social groups unprecedented intervention of the European monarchs in internal affairs of the St. Petersburg administration. Bosses of the Western world very much sought to give to the Polish revolt the status of the international conflict, without reckoning with the fact of a finding of the Kingdom Polish as a part of the Russian Empire. Due to the keen interest in "the Polish question" in the second half of the 19th century, special attention deserves work of the famous social and political activists of that time M.N. Katkov, B.N. Chicherin, A.I. Herzen and others. At the same time consideration of the main aspects of a January mutiny in Poland will not be full without analysis of the Slavophile model. The research of printing works of I.S. Aksakov will allow us to delve deeper into the principles of creation of the Polish theory of Slavophiles. The topical character of our subject is dictated by the current unstable geopolitical environment, the threat of shaking of the multipolar world. More and more obvious is the development of separatist tendencies.

Review of the literature. At different stages of formation of the domestic historiography lighting history of the Polish revolt $(1863-1864)$ and the reaction of the Russian social and political trends to it, the important place was allocated to a Slavophile perspective. Many researchers considered I.S. Aksakov the thinker, the most deeply committed to a Slavophilism letter. Even though the main polemic on "the Polish front" was developed between conservatively - the liberal union and revolutionaries - democrats, prerevolutionary and Soviet editions attached great value to the analysis the aksakovsky views. The Russian historical literature 21 is presented centuries generally by articles in scientific magazines and messengers. Here it is worth allocating M.D. Yurlova, A.A. Tesli, F.S. Sosenkova, S.I. Ivanova's works [13, 14, 28]. It is revealed that on the first place Aksakov had not state needs, but the care of the interests of the Russian people [13, p. 184]. The aksakovsky views did quite laborious work on studying the Polish scientist A. Valitsky whose works were transferred to Russian. Valitsky noted that "after the Polish revolt Ivan Aksakov" became the chief
Slavophile specialist on the Polish questions ... for many years [26, p.145]. Thereby the thesis about the relevance of aksakovsky interpretation of "the Polish question" was confirmed. It is important to track the evolution of assessment by the Slavophile Russian - Polish relations about the revolt which began in 1863 .

Purpose and tasks. The task of our work includes analysis of the most important points of the Polish revolt of 1863 - 1864 under a Slavophile point of view. In particular, the analysis of publications of I.S. Aksakov is on the agenda. Article purpose to define the extent of modification the aksakovsky views on "the Polish question" in days of a mutiny. Also, detailed clarification of the reasons for which there was a similar transformation is necessary.

\section{Problem research}

The opposition of the Russian Empire with the Western world in the 19th century reached the apogee in years $50-60$. The Parisian peace treaty, unprofitable for St. Petersburg, crowning end of the Crimean war of 1853 - 1856, uncertainty and antagonism in the relations with Europe, a difficult internal political situation only complicated world situation of Russia. For leaders of the West, the problem of rejection of the Polish and West Russian lands received by Russia as a result of three partitions of Poland at the end of the 18th century and after the Vienna congress of 1815 became an issue of utmost importance. Most sharply "the Polish question" rose in January 1863 from the beginning of a revolt in the Russian Poland. The soil for formation of two camps - the supporters and opponents who rose - was prepared by both hostility of the Polish separatists, and attempts of their European patrons by diplomatic demarches to bring contention in the social and political life of Russia. The important role in the formation of the Russian public opinion concerning the Polish revolt was played by the Slavophiles denying the western standards of development of society and state. In this article, we will in detail stop on a visible figure in the Slavophile movement - I.S. Aksakov (1823 1886). Along with A.S. Homyakov, I.V. Kireevsky, Yu.F. Samarin the son of the writer S.T. Aksakov by right was considered as one of the pillars of the Russian Slavophilism. Aksakov expressed the authoritative opinion on pages of such famous editions as "Day", Russia, Moscow, "Russian conversation". In the assessment of "the Polish question," its concept generally differed in a reality, relevance, and logicality of judgments. The Slavophile generally approved power measures of the government against the Poles who lifted a mutiny. At the same time, we will notice that at the very beginning of the Polish revolt the aksakovsky point of view dispersed from the 
policy of the St. Petersburg office occupying in general a position, irreconcilable concerning insurgents, a little. "Dopovstanchesky" contacts of a Slavophile circle with the revolutionarydemocratic community in the person of the London emigrant A.I. Herzen was not also a secret. It expressed unanimity with the Poles wishing independence to the detriment of the interests of Russia and its people though as opposed to insurgent ideology put needs of the peasantry slightly above, than an ethnic question. So, we will try to understand sources of updating of the Polish doctrine of Aksakov in details. Let's begin with a problem of the history of inclusion of Poland in the structure of the Russian Empire. In the run-up to the revolt by Aksakov it was claimed that possible withdrawal of Poland would serve for Poles as a historical lesson, and St. Petersburg was recommended to disengage"... all troops and all Russians of the administration from the Kingdom Polish, having provided to Poles to be known with itself" [17, p. 260]. Presence of the Kingdom Polish could lead to loss of control of the integrity of the state. By words A.A. Tesli, for Slavophiles loss of the Polish lands "... painful for the empire, will be favorable for national business, removing a problem of management of alien edge and need for some degree to consider the interests of the Polish citizens of the Russian tsar" [22, p. 210 - 211]. Therefore, orientation to upholding of national, but not the state interests was the priority direction for Aksakov and his comrades. If desired here it is possible to see and a certain analogy to thoughts of the liberal B.N. Chicherin who claimed that "the separation of Poland will give Russia a free hand will be cut off from it by painful gain..." [8, p. 316]. However the aggression of rebels which began in January 1863 for a while "muffled" rhetoric of the Slavophile concerning the expediency of office of the Kingdom Polish. Practically at the beginning of the revolt (on February 8, 1863), the Russian philosopher presented own vision of the situation as follows: "Recognizing behind Polish... nationality, the full moral authority for freedom of life, life and in general political independence, we do not recognize as the moral right of claim of Poland for the restoration of its former political formation at all..." [8, p. 29 - 30]. In questions the panskikh claims on the Western edge it is also simple to make out aksakovsky counteraction to this phenomenon. Even in the fall of 1861, Aksakov adhered to the critical line in the relation "... Poles for the fact that they spoil the right cause unlimited claims" [17, p. 261]. The destructive policy of heads of a mutiny only set in the strengthened motion similar moods in Slavophile community. Expansion of borders of the Polish-Lithuanian Commonwealth at the expense of the western outskirts of Russia was not entered in the concept of historical justice. The future of the Lithuanian, Little Russian and Belarusian territories had to be solved, according to the Slavophile, not at meetings of the insurgent government, and residents of these areas. Here, respectively, three versions of a succession of events were possible - to adjoin Poland in case of gaining of independence by it, to remain under the care of Alexander II or to proclaim the creation of own state educations. The last option as it is possible to assume was the least probable given existence of more influential powers on the continent which had an opportunity to stop any separatist aspirations. "... Russia has the moral right for a reunion with White and Southern Russia, same as Poland to a reunion with Poznan and Krakow ..." [8, p. 30], - Aksakov developed the idea. Thus, admitted to them a possibility of a return by Prussia and Austria of "primordial Polish lands" to Poles, on one hand, and the preferential right of Russia to the Western edge with another. At the same time with repayment of the last centers of "a rebellious flame," the thinker returned to a thesis about the undesirability of finding of the Kingdom Polish in the Russian Empire. Diplomatic confrontation Russia-Europe was another important subject of discussion connected with assessment by I.S. Aksakov of the Polish revolt of $1863-1864$. It should be noted that for the spring - summer of 1863 the peak Russian-European conflict at the level of the top officials of the states and heads of Foreign Ministries had. Mailing by Great Britain, France, and Austria of diplomatic dispatches to St. Petersburg provoked an unprecedented patriotic upsurge in the Russian society [19, p. 141-147]. Not only it is conservative - nationalist associations, but also many liberals (for example, B.N. Chicherin) blamed insurgents and their henchmen in Western Europe. Got as well solidary with raised to the Russian revolutionaries - to democrats. In the same row with critics of the anti-Russian hysteria in the West, there was also Aksakov who exposed the false and double-faced political policy of the western monarchs aiming at the geopolitical weakening of the Fatherland. At the same time long before the revolt and destructive steps of the West the publicist also released critical remarks to the European leaders. The national policy of Russia, in his opinion, "... was more straight also honest politicians of England or Austria" [8, p. 4]. Logically, unflattering judgments of I.S. Aksakov received continuation and after unleashing of diplomatic war. To that its article for July 1863 serves as the evidence. "Concerning diplomatic intervention of Europe in the Polish question" [8, p. 82 - 85]. First, the member of the union of Slavophiles sincere indignation concerning denial by Europe of a unification of the Russian government circles and the people in counteraction to diplomatic pressure from its party was expressed [8, p. 82]. 
This moment was extremely important for it as to "priest - shlyakhetsky" a mutiny and after its start, Aksakov put the interests of the Russian people on a step above, then state. Finally, the unity of the power and most of the population in many respects promoted a victorious gait of Alexander II and the Minister of Foreign Affairs A.M. Gorchakov in the protection of national interests. Secondly, addressing London and Vienna, he did not fail to remind them of their territorial problems. In particular, England the complication of its relations with India, and Austria was remembered (by the way, the participant of Three partitions of Poland) it was offered to recognize beyond Russia "... the right of intervention in affairs next to us or relatives from our borders of the Austrian areas of Galicia, Bukovina, Czech Republics, Hungary" [8, p. 84]. The possibility of "moving away" of borders of the empire in the east direction at the expense of territorial concessions to Poles was denied. But one of the most essential factors on which Aksakov stopped was even not possible western intervention, but presence at an insurgent cohort at Europe of natives of Russia. All this, of course, could not but affect the tone of its publications. Being in the French capital in 1863, the thinker besides the fact of treachery from compatriots with bitterness stated the European contempt for such "deserters". Directly point excerpts from the Parisian letter to newspaper editorial office "Day" to it: "... if Europe also uses their services, then with the same feeling with what the military leader uses services of the traitor - the spy or the deserter from the hostile camp!" [19, p. 112]. Alliance with unfriendly to the Fatherland elements in other countries - anything, according to Aksakov, the unjustified act of high treason. For example, the ideologist of the Russian anarchism M.A. Bakunin, the ardent ally of insurgents, was designated by him as "... leading the Polish group, or gang of any crowd of masters, journeymen, and workers of revolution, hunters till it bleeds ..." [19, p. 112]. Beyond admissible, there were bakuninsky declarations on promises of "donation" of the Polish-Lithuanian Commonwealth of the Russian areas, and Sweden - Finland. Thus, government circles of the West, composing notes of protest and enjoying the support of the Russian revolutionaries and anarchists, tried to incline the St. Petersburg administration to capitulation. However received worthy repulse not only from the leadership of Russia but also patriotically adjusted public figures - Slavophiles, conservatives, liberals. The third aspect of our research includes problems of religion, confessional relationship in the Kingdom the Polish and Western edge. Opening by insurgents of military operations against the central power made the inevitable collision of two branches of Christianity - Catholicism and
Orthodoxy. Promotion of insurgent ideals by the Polish and West Russian Catholics, finding of priests in fighting formations were one of the mutiny dominants in Poland. Due to the statement of a religious question, we will consider the point of view of I.S. Aksakov. Updating a spiritual question, the thinker "... saw guarantee of strengthening of the state unity and prophylactic of centrifugal trends especially in the western provinces in the distribution of orthodox belief" [20, p. 183]. Promoting of Orthodoxy, Russian in the Western region and actually in the territory of ethnic Poland, thus, quite fitted into the system of coordinates of Aksakov. However, when the insurgent wave began to come to naught, gradual withdrawal of the Slavophile ideologist from the need of russification of Poland began. However, concerning the West Russian provinces, its concept did not undergo significant changes. The publication "Catholicism — the Mightiest Means of an Opolyacheniye" in many respects sheds light on its relation to this perspective [8, p. 312 - 317]. The author, in general abstaining from criticism of Catholic religion per se, noticed that in the western outskirts of Russia it is necessary to take away the clothes of the Polish nationality from Catholicism (to denationalize the Polish Catholicism)" [8, p. 314]. Therefore, the spiritual subject was closely tied to a polonizm problem. It, but not Poland, according to Aksakov's interpretation, was the main headache RussianPolish civilization dialogue [8, p. 154 - 160]. On the other hand, Aksakov noted that "dissociation of Catholicism with the Polish nationality through not Polish - would be dissociation purely external" [8, p. 315]. In other words, only one introduction of Russian in a Catholic church service will not become the solution of a difficult task of maintenance of religious balance in the western lands to the Russian Empire. Let's notice, for example, that the Polish influence on Lithuanian-Ukrainian lands - "... moral power which relies on society and officials - Poles and finds in it the corresponding reflection..." [26, p. 152 - 153]. It was offered "to settle" this situation by the formation of a powerful kernel of Russian intelligentsia there. Thus, Catholicism "in the Polish appearance" was presented to Aksakov as the most radical and dangerous component for imperial religious policy in the region. At the same time, certain mitigation of the anti-Polish rhetoric in a religious question was connected with suppression of the rebellious centers in the Kingdom Polish, Lithuania, Ukraine, and Belarus.

\section{Conclusions}

Summing up the analysis of the opinion of I.S. Aksakov on the Polish revolt of 1863 - 1864, we will draw several conclusions. So, if on the eve of the January events of 1863 the Slavophile did not 
consider the big tragedy finding of independence by Poland, then from the beginning of an active phase of fighting the Polish doctrine of Aksakov was sharply developed "to the right". His thoughts reminded more and more the theory of "antipolonizm" which during the revolt was constantly declared by the Russian conservatives. But, on the other hand, as by us it was noticed, one of his statements contained an obvious hint to the Austrian and Prussian governors on a possibility of a return by them in a bosom of the Polish-Lithuanian Commonwealth of the Krakow and Poznan lands. Diplomatic war with the European monarchy finally undermined Aksakov's belief in the probability of search of a compromise with the West and the Polish rebellious government. In other words, the Russian publicist rejected any feeble efforts of Europeans to place the St. Petersburg office in a political-legal vacuum, to adhere to the rigid sanctions line in its relation. At last, formulating the Polish credo, the Slavophile considered important preaching of the orthodox ideas in Poland and the western Russian areas. Besides, the aksakovsky religious theses disposal of Catholicism in the Western region from the Polish influence became one of the focal points. Thus, without calling into question the predominating role of the Russian conservative community, the union of Slavophiles is designated by us as one of the key players in questions of protection of national interests during the dramatic events in Poland. Actions of rebels, the intervention of Europe in Russian-Polish conflict forced I.S. Aksakov and his colleagues to depart for a while from the theory of potential obtaining independence by the Kingdom Polish. At the same time, the views of the Slavophile from the moment of suppression of a mutiny underwent certain changes towards expediency of an exception of Poland of the Russian imperial possession.

\section{Acknowledgements}

The publication has been with the support of the "RUDN University Program 5-100".

\section{References}

"Russian archive": Fatherland history in certificates and documents of the XVIII-XX centuries. Almanac: Issue XIII. M.: Editorial office of the almanac "Rossiysky Arkhiv", 2004. -544 p.

Adonina L., Bondareva O., Fisenko O. Ismailova K. The Creation of Methodology of Technical Universities Students' Intellectual Skills Formation and

Development in the Foreign Language

Course with the Consideration of Cognitive

Processes Flow // European research studies journal. - Vol. XXI. - 2018. - P.124 - 131

Adonina L.V., Rumyantseva N.M., Fisenko O.S. Management of Education in the Concept of Educational and Pedagogical Teachings of M.M. Speranskii //

International Journal of Control Theory and Applications. - V. - № 10. - 2017. - 187197

Aksakov I. S. Complete works. T. 3. The Polish question and West-Russian business. Jewish problem. 1860 - 1886. St.-

Petersburg: Edition of the imperial public library, 1900 . -570 pages.

Aksakov I.S. Complete works. T. 2

Slavophilism and Westernism. 1860 - 1886 St.-Petersburg: A.S. Suvorin's printing house, 1891. -835 pages.

Aksakov Ivan Sergeyevich in his letters. Part 2. Letters to different persons. T. 4. Letters to M.F. Rayevsky, to A.F. Tyutcheva, to the countess A.D. Bludova, to N.I. Kostomarov, to N.P. Gilyarov - to Platonov. $1858-86$ St.-Petersburg: Edition of the imperial public library, 1896.

Ananyev S. V. 150 - the anniversary of the beginning of the Polish revolt (the historiographic review)//the SGTU Bulletin No. 3 (72). Saratov: SGTU, 2013. $193-197$

Bryntsev P.D. Polish mutiny of 1863 of Vilna: A.G. Syrkin's printing house, 1891 263 pages.

Filevich I.P. And. S. Aksakov and the Polish question (I.P. Filevich's Speech readings in a solemn meeting of S. - the St. Petersburg Slavic Charitable Society on February 14, 1887). St.-Petersburg: Printing house E. Evdokimova, 1887. - 8 pages

Ivanova S.I. Discussion of "the Polish question" on pages of periodicals $60-\mathrm{x}$ years of the 19th century//Year-book of Russian - Polish Institute. No. 1 (2).

Wroclaw: Russian - Polish Institute fund, 2012. $9-32$

Kargina N.V., Ficenko O.S., Polyanskaya E.N. Technology of social management in an organization in the Russia federation: the theoretical aspect // The Turkish online Journal of Design Art and Communication TOJDAC, December 2017 Special Edition. - 2017. - P. 1970-1979

Kitayev V.A. From opposition to okhranitelstvo (from the history of the Russian liberal thought $50-60-x$ years of the 19th century). M.: Thought, 1972. 288 pages.

Kitayev V.A. The liberal thought in Russia (1860 - 1880). Saratov: Saratov. Univ., 2004. 379 pages.

Kruzhalina A.A. The Polish question in discussions of the Russian public of the 19th century//Messenger of BGU. History. No. 7. Ulan-Ude: BGU, 2013. 142 - 146

Kudryashev V.N. "The Ukrainian question" in the Russian social thought of the second half of the 19th century//Messenger of Tom. state. univ. No. 384. Tomsk: TGU, 2014. $107-115$

Mayorova $\mathrm{O}$. War and myth: the memory of a victory over Napoleon in days of the Polish revolt (1863 - 1864)//the New literary 
review: The first independent Russian philological magazine. 2012. No. 118. http://www.nlobooks.ru/node/2899

Misko M.V. Polish revolt of 1863. M.: Academy of Sciences of the USSR, 1962. 336 pages.

Radchenko A.A. Slavophiles about Severo's "russification" - the Western region of the Russian Empire//Scientific sheets of BELGU. Series: History. Political science. Economy. Informatics. No. 13 (84). Century 15. Belgorod: NIU "BELGU", 2010. 140 145

Sidorov A.A. Polish revolt of 1863.

Historical sketch. St.-Petersburg: N.P.

Karbasnikov's edition, 1903. 256 pages

Sosenkov F. S. "The Polish question" in the politician - legal views of I.S.

Aksakov//Innovative science. No. $1-2$.

Ufa: LLC Aeterna, 2015. $182-18$

Tesli A.A. Herzen and

Slavophiles//Sociological review. No. 1. T.

12. M.: NIU "HSE", 2013. 62 - 85

Tesli A.A. Slavophilism history stages in the context of nationalism researches//the

TOGA Bulletin. No. 3 (22). Khabarovsk:

TOGA, 2011. $207-216$ p.

The collection of articles printed in different periodicals on the occasion of I.S. Aksakov's death (27 January 1886). Moscow: L.F. Snegirev's printing house, 1886 . -300 pages.

Tvardovskaya V.A. Ideology of post-reform autocracy. M.: Science, 1978. 280 pages.

Valitsky A. History of the Russian thought from education to Marxism. M.: "Canon" of ROOI "Rehabilitation", 2013. 480 pages.

Valitsky A. Russia, Catholicism, and Polish question. M.: Publishing house of Moscow University, 2012. 624 pages.

Yanov L. Slavophiles and foreign policy of Russia in the 19th century. URL:

www.civisbook.ru (date of the address: 22.01.2017)

Yemelyanov E.P. An ethnic question in I.S. Aksakov and N.I. Kostomarov's correspondence//Scientific dialogue. No. 6 (18): History. Sociology. Ethnography.

Yekaterinburg: LLC Center of Scientific and Educational Projects, 2013. P. $21-29$

Yurlova M.D. To observe and participate: a biography of the main Russian

Slavophile//Sociological review. No. 2. T.

14. M.: NIU "HSE", 2015. $169-176$

Zelenin A.V. Historiosophical and social views of I.S. Aksakov in the assessment of the American researcher S. Lukashevich//Scientific problems of humanitarian researches. History. No. 1. Pyatigorsk: Institute of regional problems of the Russian statehood in the North Caucasus, 2011. P.248 - 254 Interpretation of an Image of a Historical Character: Duchess de Polingac in Fiction and Biopic / M. Kozyreva, K. Ayupova.// The Turkish online Journal of Design and Communication: Turkey, TOJAC, November, Special Issue, 2016. P. 2397$2402 /$

O. Baratova, V. Shamina, \& E. Apenko Metaphors of Postmodernism in Neo-
Victorian Fiction: "The Trial of Elizabeth Cree" by Peter Ackroyd and \&The Decorator" by Boris Akunin. Journal of History Culture and Art Research, 6(5), 2017, P.139-144.

Conversations with Anthony Burgess. Jackson: University Press of Mississippi, 2008. 189 p.

G. S. Trunkville. Life of the twelve Caesars. Translation by M.L. Gasparov. Moscow: Pravda, 1988. 204 p.

K. Tacitus. Works in two volumes. Volume I. "Annals. Small works»». Scientific-ed. Center "Ladomir", Moscow, 1993. 448 p.

A. Burgess You've had your time. London: Vintage Books, 2002. $450 \mathrm{p}$. 